\title{
Aetiology of acute diarrhoea in adults
}

\author{
J JEWKES, * H E LARSON, $\dagger$ A B PRICE, P J SANDERSON, $\ddagger$ AND H A DAVIES \\ From Northwick Park Hospital and Clinical Research Centre, Harrow, Middlesex
}

SUMMARY We have studied 73 adults with acute diarrhoea and identified a micro-organism or toxin likely to be the cause in $58 \%$. In addition to routinely cultured bacteria, Campylobacter coli/jejuni and Clostridium difficile were important pathogens in the community. Patients who developed diarrhoea after antibiotic use had a distinctive clinical syndrome and comprised the third largest group of cases. Clinical, epidemiological, and histological features in an additional group with negative cultures and no antibiotic history suggest that an additional bacterial pathogen remains to be identified as a cause of acute diarrhoea in adults.

Acute diarrhoea is a common cause of hospital admission. In children an aetiology can be documented in $83 \%$ of the cases, infection with rotavirus being the most frequent. ${ }^{12}$ In contrast, in adults a specific cause is found in only $27-36 \% \%^{13}$ We undertook a prospective study of diarrhoea in adults in order to try to improve on this diagnostic rate by the application of methods for newly identified gastrointestinal pathogens such as Campylobacter coli/ jejuni and Clostridium difficile. This paper compares the relative frequency and symptomatology of the different infections.

\section{Methods}

Between July 1978 and July 1979, 106 patients aged from 15 to 94 years were admitted to Northwick Park Hospital with acute diarrhoea on the initial presumption that it was of an infective origin. In 12 patients the diarrhoea ceased on admission and in five more adequate stool samples were not collected. These cases were excluded. Another 16 were rejected because their final diagnosis was not infective diarrhoea. These comprised two new cases of ulcerative colitis, one exacerbation of known Crohn's disease, two Gram-negative septicaemia, three spurious diarrhoea due to faecal impaction, and one case each of faecal incontinence, irritable

*Present address: Brompton Hospital, London, SW3.

†Address for reprint requests: Dr H E Larson, Division of Communicable Diseases, Clinical Research Centre, Watford Road, Harrow, Middlesex HA1 3UJ.

$\ddagger$ Present address: Edgware General Hospital, Edgware, Middlesex HA8 0AD.

Received for publication 2 December 1980 bowel syndrome, pancreatic steatorrhoea, postvagotomy diarrhoea, and Stevens-Johnson syndrome (involving the rectal mucosa). Therefore 73 patients remained for study.

The infectious disease unit draws from communities over a wide area of suburban north-west London. This includes the full range of social classes as well as Indian and West Indian ethnic minorities. The clinical history and physical examination were documented on a standard proforma by one observer (JJ). Specific questions on antibiotics, foods, and affected relatives were included. Abdominal pain was graded as absent, mild, or severe.

A sample of faeces was collected within 24 hours of admission and cultured by conventional procedures for Salmonella, Shigella, Campylobacter, Yersinia, and Candida spp. Direct light microscopy for leucocytes and parasites was carried out. A sample was also frozen at $-70^{\circ} \mathrm{C}$ and later tested in tissue culture for viruses and Clostridium difficile toxin. Electron microscopy was performed on faecal suspensions, both directly and after caesium chloride density gradient separation, in 29 out of the 36 patients in whom all other tests were negative.

Sigmoidoscopy was carried out in 53 patients while diarrhoea was still present. A satisfactory rectal biopsy was obtained in 49 . No bowel preparation was used. At the end of the study, the biopsies were coded and interpreted by one of us (ABP) without knowledge of the clinical or microbiological findings. They were classified into one of the following categories: normal, oedematous, mild active proctitis, typical infective proctitis, ${ }^{45}$ chronic inflammation, ${ }^{3}$ pseudomembranous colitis (PMC), ${ }^{6}$ or ulcerative colitis. The term 'mild active proctitis' was used when the only abnormality in the biopsy 
was isolated foci of polymorphs within the lamina propria or invading the epithelium and crypts.

Statistical analysis of frequency tables was performed by means of the chi-square test or by Fisher's exact probability test if frequencies were small. Continuous variables-for example, temperature, duration of diarrhoea-were compared using the Mann-Whitney U-test. All significance levels quoted are two-tailed.

Patients were treated with intravenous fluids, clear liquids, and bulking agents as clinically indicated. Opiates, anticholinergic drugs, and antibiotics were not given routinely. Metronidazole was used for giardiasis and vancomycin for PMC.

The study was approved by the ethical committee of the Harrow Health District.

\section{Results}

The micro-organisms identified are listed in Table 1. A specific cause was found in 42 patients $(58 \%)$, the largest group being $31(42 \%)$ with salmonella, shigella, or campylobacter infections. Salmonella and Campylobacter spp. caused approximately equal numbers of infections.

Viruses were responsible for only five cases, but three rotavirus infections are noteworthy (ages 45, 62 , and 87 years). In two patients, virus particles having the morphological and buoyant density characteristics of Norwalk-type viruses were found. No viruses were recovered in tissue culture. Three patients from abroad had giardiasis. C. difficile toxin was detected in four patients, only two of whom had recently taken antibiotics.

Three patients had mixed infections. From one Campylobacter and Salmonella spp. were isolated, in a second Shigella flexneri was found together with vegetative forms of Giardia lamblia and cysts of Entamoeba histolytica, and in the third both $C$. difficile toxin and Giardia cysts were detected.

Table 1 Pathogens identified in 71 patients with diarrhoea

\begin{tabular}{lrrl}
\hline \multicolumn{1}{c}{ Pathogen } & $\begin{array}{l}\text { Found in whole } \\
\text { study }\end{array}$ & \begin{tabular}{l} 
Found in 13 who had \\
recently taken \\
\cline { 2 - 3 }
\end{tabular} & $\begin{array}{l}\text { (no.) } \\
\text { antibiotics } \\
\text { (no.) }\end{array}$ \\
\hline Salmonella spp & 14 & $19 \cdot 2$ & 0 \\
Campylobacter spp & 13 & $17 \cdot 8$ & 0 \\
Shigella flexneri & 5 & $6 \cdot 8$ & 0 \\
Clostridium difficile & 4 & $5 \cdot 5$ & 2 \\
Giardia lamblia & 3 & $4 \cdot 1$ & $1 \dagger$ \\
Rotavirus & 3 & $4 \cdot 1$ & 0 \\
Norwalk-type virus & 2 & $2 \cdot 7$ & 1 \\
Candida albicans & 1 & $1 \cdot 4$ & 1 \\
None & 31 & $42 \cdot 5$ & 9 \\
\hline
\end{tabular}

-Total exceeds 73 because of mixed infections (see tcxt). †This patient also had $C$. difficile toxin.
Table 1 also lists 13 patients who developed diarrhoea after taking antibiotics. Seven received ampicillin or amoxycillin, two cephalexin, two cotrimoxazole, one tetracycline, and one a combination of these. In six cases the antibiotics had been given for upper respiratory symptoms only. The number of patients who took antibiotics and from whom no pathogen was isolated is disproportionately large (Table 1). This group forms a significant cluster when compared with the number who took antibiotics and did have a pathogen identified $(P<0.03)$.

Table 2 summarises the clinical features in relation to the micro-organisms isolated. Patients with virus infections had diarrhoea for the shortest period. In contrast, the four patients positive for $C$. difficile toxin had diarrhoea for eight, 22, 24, and 48 days. The clinical features of salmonella and campylobacter infections were compared separately, but only one of the differences was significant. Diarrhoea was more prolonged in salmonellosis (10 vs eight days, $\mathbf{P}<0.05$ ) but abdominal pain was more often severe and was more prolonged (three $v s$ one day) in campylobacter infection. Indeed, two patients underwent laparotomy because of this, with negative findings.

The patients from whom no pathogens were isolated had a distinctive clinical picture, and six features were significantly different from the group with salmonella, shigella, and campylobacter infections (Table 2). They tended to have a short sharp diarrhoeal illness, with leucocytosis, mild fever, bloody stools, and colicky abdominal pain. Even when this group is subdivided into those who took antibiotics and those who did not, the clinical differences persist.

The Figure compares the epidemiology of the different infections. Cases of salmonella, shigella, and campylobacter infection occurred mainly in the summer months, as expected, whereas cases with no identified pathogen occurred throughout the year.

Few patients gave a history of eating suspicious food or of having an affected contact. Twelve out of the 31 patients with proven salmonella, campylobacter, or shigella infection did so, compared with only four of the 31 with no identified pathogen $(P<0.025)$. In each of these groups, seven and three patients respectively had recently been abroad. None of the patients who took antibiotics and who had no pathogen identified had any of these features.

The rectal biopsies are classified in Table 3. The typical picture of infective proctitis was seen in 22 $(44 \%)$, and most consistently in those with campylobacter infection. The biopsies from the patients with viruses were normal. Twenty of the 23 patients who had no pathogen isolated had some abnormality on biopsy. The spectrum of the changes was 
Table 2 Comparison of clinical features in different aetiological groups

\begin{tabular}{|c|c|c|c|c|c|c|}
\hline \multirow[t]{2}{*}{ Feature } & \multirow{2}{*}{$\begin{array}{l}\text { Salmonella } \\
\text { Campylobacter } \\
\text { Shigella }(n=31)\end{array}$} & \multirow[t]{2}{*}{ Viruses $(n=5)$} & \multirow{2}{*}{$\begin{array}{l}\text { Clostridium } \\
\text { difficile }(n=4)\end{array}$} & \multicolumn{3}{|c|}{ No pathogen isolated } \\
\hline & & & & All $(n=31)$ & $\begin{array}{l}\text { No previous } \\
\text { antibiotic }(n=22)\end{array}$ & $\begin{array}{l}\text { Antibiotic } \\
\text { associated }(n=9)\end{array}$ \\
\hline \multirow{6}{*}{$\begin{array}{l}\text { Highest temperature during } \\
\text { admission (median, }{ }^{\circ} \mathrm{C} \text { ) } \\
\text { White cell count } \\
\left.\text { (median } \times 10^{\circ} / 1\right) \\
\text { Diarrhoea duration before } \\
\text { admission (median, days) } \\
\text { Total duration of diarrhoea } \\
\text { (median, days) } \\
\text { Number of stools on worst } \\
\text { day (median) } \\
\text { Number }(\%) \text { reporting frank } \\
\text { blood in stool } \\
\text { Number }(\% \text { ) with severe } \\
\text { abdominal pain } \\
\text { Duration of pain after } \\
\text { admission (median, days) }\end{array}$} & $38 \cdot 0$ & $36 \cdot 5 \ddagger$ & $37 \cdot 3$ & $37 \cdot 0 \ddagger$ & $37 \cdot 3 *$ & $37 \cdot 0 *$ \\
\hline & $8 \cdot 1$ & $7 \cdot 3$ & $9 \cdot 2$ & $10.8+$ & $10 \cdot 7 *$ & $11 \cdot 8 *$ \\
\hline & 4 & 2 & 14 & 2 & 2 & 2 \\
\hline & 10 & $5 \dagger$ & 23 & $6 \ddagger$ & $7 \ddagger$ & $5+$ \\
\hline & $\begin{array}{l}10 \\
8 \\
(26 \%) \\
10 \\
(32 \%)\end{array}$ & $\begin{array}{l}9 \\
2 \\
(40 \%) \\
1 \\
(20 \%)\end{array}$ & $\begin{array}{l}9 \\
1 \\
(25 \%) \\
0 \\
(0 \%)\end{array}$ & $\begin{array}{l}15 \% \\
18 \dagger \\
(58 \%) \\
18 \\
(58 \%)\end{array}$ & $\begin{array}{l}15 \\
12 \\
(55 \%) \\
12 \\
(55 \%)\end{array}$ & $\begin{array}{l}20 \\
6 \\
(67 \%) \\
6 \\
(67 \%)\end{array}$ \\
\hline & 2 & 1 & 1 & $1 *$ & $1 *$ & 1 \\
\hline
\end{tabular}

Difference from group infected with Salmonella, Campylobacter or Shigella spp. significant at *p $<0.05,+p<0.025$, and $\ddagger p<0.01$ respectively. Differences between the no pathogen/no antibiotic group and the no pathogen/antibiotic-associated group are not significant.

Table 3 Rectal biopsies classified according to pathogen isolated, in 48 patients*

\begin{tabular}{|c|c|c|c|c|c|c|}
\hline Pathogen isolated & Normal & Oedema & $\begin{array}{l}\text { Mild active } \\
\text { proctitis }\end{array}$ & Infective & $\begin{array}{l}\text { Chronic } \\
\text { inflammation }\end{array}$ & $P M C$ \\
\hline $\begin{array}{l}\text { Salmonella spp } \\
\text { Shigella flexneri } \\
\text { Campylobacter spp } \\
\text { Clostridium difficile } \\
\text { Viruses } \\
\text { Candida } \\
\text { No pathogen no antibiotic } \\
\text { No pathogen recent antibiotics }\end{array}$ & $\begin{array}{l}\mathbf{0} \\
\mathbf{1} \\
\mathbf{0} \\
\mathbf{0} \\
\mathbf{3} \\
\mathbf{0} \\
\mathbf{1} \\
\mathbf{2}\end{array}$ & $\begin{array}{l}2 \\
0 \\
0 \\
0 \\
0 \\
0 \\
1 \\
1\end{array}$ & $\begin{array}{l}3 \dagger \\
1 \\
0 \\
0 \\
0 \\
0 \\
3 \\
4\end{array}$ & $\begin{array}{r}2 \\
0 \\
10 \\
1 \\
0 \\
1 \\
7 \\
1\end{array}$ & $\begin{array}{l}\mathbf{0} \\
\mathbf{0} \\
\mathbf{0} \\
\mathbf{0} \\
\mathbf{0} \\
\mathbf{0} \\
\mathbf{3} \\
\mathbf{0}\end{array}$ & $\begin{array}{l}\mathbf{0} \\
\mathbf{0} \\
\mathbf{0} \\
\mathbf{1} \\
\mathbf{0} \\
\mathbf{0} \\
\mathbf{0} \\
\mathbf{0}\end{array}$ \\
\hline
\end{tabular}

"One other patient with salmonellosis had a biopsy typical of ulcerative colitis (see text).

tIncludes the patient with mixed salmonella and campylobacter infection.

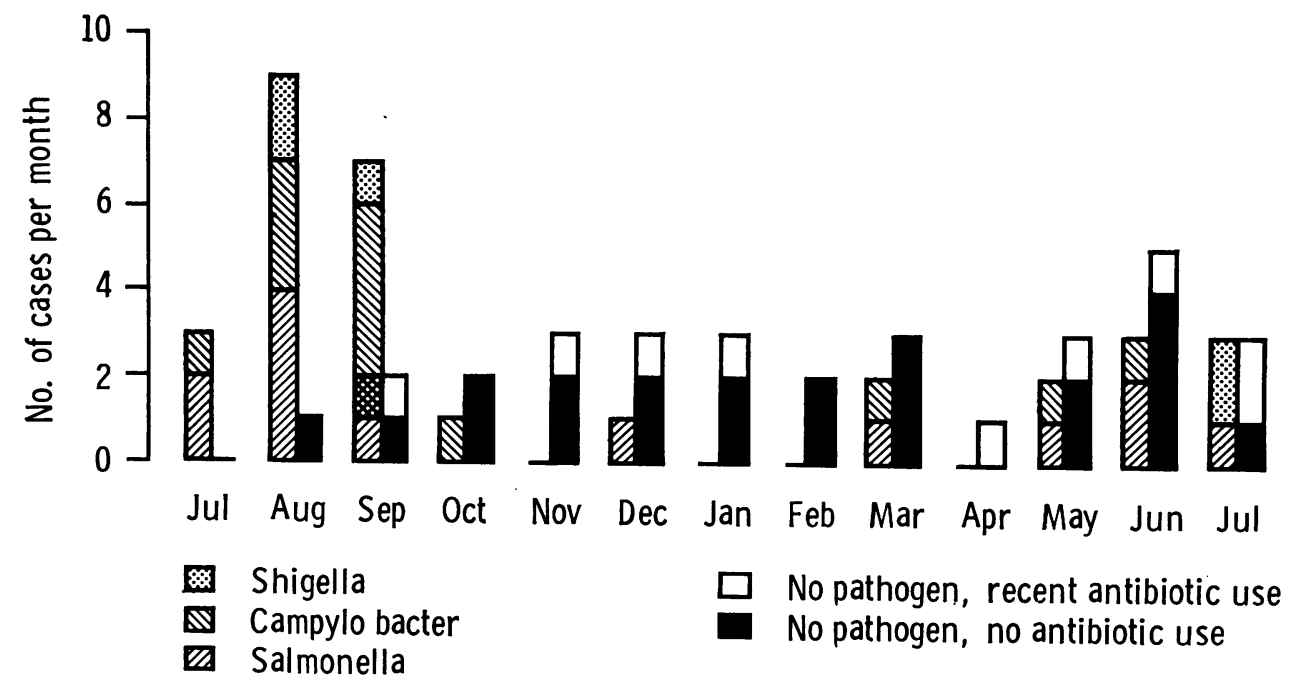

Figure Number of cases presenting in each month, according to aetiology. 
qualitatively similar to those in salmonella, shigella, or campylobacter infection, although only a single patient in the antibiotic group had the typical infective changes. The histological picture did not correlate with the severity of the diarrhoea, the faecal leucocyte count or the sigmoidoscopic appearance.

One patient with salmonella infection had a biopsy typical of ulcerative colitis (not shown in Table 3). She recovered fully from the diarrhoea but five months later relapsed with clinically typical ulcerative colitis. This was the only patient in the study to return with diarrhoea during the six to 18 month follow-up period.

\section{Discussion}

Patients with acute self-limiting diarrhoea are usually given a clinical diagnosis of infective diarrhoea even if no pathogens are found in the stools. Although this is a reasonable approach to the management of individual patients, in scientific terms the diagnosis remains unknown.

In a previous study from our hospital, microorganisms were detected in 14 of 52 patients over the age of 15 years, while Dickinson, Gilmour, and McClelland found salmonella and shigella in 13 of 36 patients with a diagnosis of infective diarrhoea. ${ }^{13}$ We have identified a pathogen in $58 \%$ of our patients, a substantial improvement over other series. Bacteria were the most important but techniques other than bacterial culture were necessary to make the diagnosis in 12 cases $(17 \%)$. Our findings agree with previous reports that Campylobacter spp. are identified with approximately the same frequency as Salmonella spp. ${ }^{7-9}$ Routine culture of stools should therefore include specific methods to identify Campylobacter spp.10 Salmonella and campylobacter infections are difficult to distinguish clinically, although severe pain might suggest the latter. Rectal biopsy in campylobacter infection consistently shows infective proctitis. ${ }^{5}$

To our knowledge there are no previous studies which have attempted to assess the role of $C$. difficile in unselected patients with infective diarrhoea. In this study it was implicated in two patients who had taken antibiotics and in two others with no antibiotic history (Table 1). One of the latter had histological PMC and recovered after vancomycin treatment. This organism is not the main cause of antibiotic-associated diarrhoea, yet conversely can produce diarrhoea in the absence of antibiotics. The patients with $C$. difficile associated disease, whether or not it followed antibiotics, suffered prolonged diarrhoea.

Viruses were found in five cases. It is known that symptoms may persist for only 24 hours after infection with Norwalk-type viruses ${ }^{11}$ and it is possible that many of the cases whose diarrhoea had ceased on admission fell into this category. Nevertheless, three patients excreting rotavirus warranted admission to hospital. The electronmicroscopic methods used to detect Norwalk-type viruses are laborious and this effort was therefore limited to those patients with negative bacterial cultures. Thus we have not excluded the possibility of mixed viral and bacterial infections.

There were 31 patients $(42 \%)$ in whom no microorganism could be identified as a cause of the diarrhoea. The clinical findings and epidemiology of these cases were different from those with salmonella, shigella and campylobacter infection (Tables 2 and 4). Such findings argue against the explanation that they represent cases from whom we failed to culture routine pathogens.

Antibiotic therapy preceded diarrhoea in nine of these patients. Their illnesses were characterised by the sudden onset of frequent bloody stools, colicky abdominal pain, and by subsequent rapid resolution. It is arguable that antibiotic treatment suppressed the faecal excretion of known pathogens, but the antibiotic treatment preceded the diarrhoea and their clinical presentation was unique. A more likely explanation in our opinion is that they represent a type of antibiotic-associated colitis similar to the cases reported by Toffler et al. ${ }^{12}$ and by Sakurai $e t$ al. ${ }^{13}$ In these reports barium enema showed a rightsided colitis. Analogous to PMC, this type of colitis might also turn out to be an infection; our clinical and histological data are consistent with such a view. Our results also suggest that antibiotics make an important contribution to the incidence of diarrhoea in the community. Most patients did not volunteer the fact that they had been taking antibiotics, and this should be a specific question to any patient with acute diarrhoea.

Twenty-two patients remain for whom no explanation for the diarrhoea can be given, though seven of the 15 biopsied in this group showed definite evidence of infective proctitis. There are other less common micro-organisms responsible for diarrhoea for which we did not specifically test, such as invasive and enterotoxin-producing Escherichia coli ${ }^{1415}$, Vibrio parahaemolyticus, ${ }^{14}$ and Aeromonas hydrophila. ${ }^{16}$ However, their isolation is rare in Britain (Public Health Laboratory Service Communicable Disease Report 1978, unpublished) and this makes it unlikely that they are responsible for such a sizeable and uniform cluster of patients. We suggest that there still remains a bacterial pathogen which will prove to be a significant cause of diarrhoea in adults.

Biopsies from three of the above group of patients 
showed changes of chronic inflammation; this is a small number but enough to raise speculation of a link with ulcerative colitis or Crohn's disease. It is thus important to be able to establish a microbial aetiology for all cases of infectious diarrhoea in adults. The culture-negative patients are an intriguing clinical and bacteriological challenge.

We thank Dr Hillas Smith for permission to study patients under his care.

\section{References}

${ }^{1}$ Rowland MGM, Davies H, Patterson S, et al. Viruses and diarrhoea in West Africa and London: a collaborative study. Trans $R$ Soc Trop Med Hyg 1978; 72: 95-8.

${ }^{2}$ Lewis HM, Parry JV, Davies HA, et al. A year's experience of the rotavirus syndrome and its association with respiratory illness. Arch Dis Child 1979; 54: 339-46.

${ }^{3}$ Dickenson RJ, Gilmour HM, McClelland DBL. Rectal biopsy in patients presenting to an infectious disease unit with diarrhoeal disease. Gut 1979; 20: 141-8.

${ }^{4}$ Day DW, Mandal BK, Morson BC. The rectal biopsy appearances in salmonella colitis. Histopathology 1978; 2: 117-31.

${ }^{5}$ Price AB, Jewkes J, Sanderson PJ. Acute diarrhoea: Campylobacter colitis and the role of rectal biopsy. $J$ Clin Pathol 1979; 32: 990-7.

'Price AB, Davies DR. Pseudomembranous colitis. J Clin Pathol 1977; 30: 1-12.
'Pai CH, Sorger S, Lackman L, Sinai RE, Marks MI. Campylobacter gastroenteritis in children. $J$ Pediatr 1979; 94: 589-91.

${ }^{8}$ Brunton WAT, Heggie D. Campylobacter-associated diarrhoea in Edinburgh. Br Med J 1977; 2: 956.

${ }^{9}$ Pearson AD, Suckling WG, Riccardi ID, Knill M, Ware E. Campylobacter-associated diarrhoea in Southampton. Br Med J 1977; 2: 955-6.

${ }^{10}$ Skirrow MB. Campylobacter enteritis: a 'new' disease. Br Med J 1977; 2: 9-11.

${ }^{11}$ Dolin $\mathrm{R}$, Blacklow NR, DuPont $\mathrm{H}$, et al. Transmission of acute infectious nonbacterial gastroenteritis to volunteers by oral administration of stool filtrates. $J$ Infect Dis 1971; 123: 307-12.

${ }^{12}$ Toffler RB, Pingoud EG, Burrell MI. Acute colitis related to penicillin and penicillin derivatives. Lancet 1978; 2: 707-9.

${ }^{13}$ Sakurai $Y$, Tsuchiya H, Ikegami F, Funatomi T, Takasu S, Uchikoshi T. Acute right-sided hemorrhagic colitis associated with oral administration of ampicillin. Dig Dis Sci 1979; 24: 910-5.

${ }^{14}$ Guerrant RL. In: Mandell GL, Douglas RG, Bennett $\mathrm{JE}$, eds. Principles and practice of infectious diseases. New York: Wiley, 1979: 877.

${ }^{15}$ Gross RJ, Scotland SM, Rowe B. Enterotoxigenic Escherichia coli causing diarrhoea in travellers returning to the United Kingdom $\mathrm{Br}$ Med J 1979; 1: 1463.

${ }^{16}$ Wadstrom T, Aust-Kettis A, Habte D, et al. Enterotoxinproducing bacteria and parasites in stools of Ethiopian children with diarrhoeal disease. Arch Dis Child 1976; 51: $865-70$. 